\title{
The familiar versus the unfamiliar: Familiarity bias amongst individual investors
}

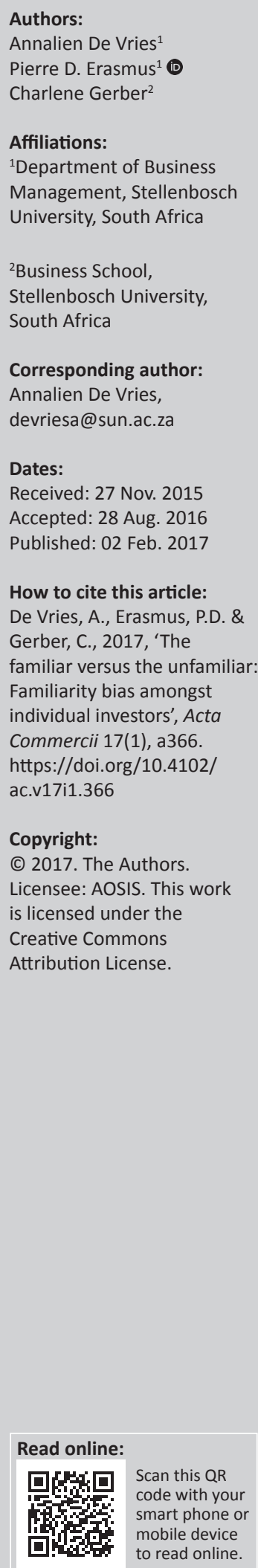

Purpose: The purpose of this study was to investigate the existence of familiarity bias amongst individual investors in the South African stock market.

Problem investigated: According to Warren Buffet, one needs to maintain emotional detachment if one wants to be a successful investor. However, recent research indicates that the perceptions of companies' products and brands may influence individuals' investment decisions in the stock market. This phenomenon implies that the investment decisions of individual investors are not purely based on firm fundamentals as suggested by traditional finance theories, but might be driven partly by the positive or negative attitude they have towards certain companies' products and brands. The existence of familiarity bias amongst individual investors was investigated to determine if individuals prefer to invest in companies they are familiar with as opposed to unfamiliar companies.

Methodology: A quantitative approach was followed. An online survey was used to show images of familiar and unfamiliar company brands to respondents, whereafter respondents were asked to indicate whether they will invest in the shares of the identified companies. The statistical analysis entailed descriptive statistics as well as one-way analyses of variance to test the stated hypotheses.

Main findings: The results of this exploratory study indicate that investors do exhibit familiarity bias when choosing between different companies to invest in.

Value of the research: The inclination of individual investors to invest in familiar corporate brands can have implications for the marketing industry, financial markets, the performance of companies as well as the investment performance of individual investors in the sense that it would seem that company brands could have an influence on investment decisions.

\section{Introduction}

Traditional finance theory attempts to give an understanding of financial markets by applying models that are based on the assumption that individual investors are rational and, therefore, hold well-diversified portfolios. For years, this assumption of individual rationality has been accepted as the cornerstone of traditional finance models. According to these models, the market price of a security is equal to its fundamental value. The fundamental value (also referred to as book value or intrinsic value) of a stock refers to the value of the stock based on financial statement analysis, without referring to its value in the market. The reason behind the argument that price equals fundamental value is based on the Efficient Market Hypothesis $(\mathrm{EMH})$. If stock prices deviate from their fundamental values, rational investors would immediately recognise and react to this, thereby correcting the mispricing. However, empirical evidence (Cutler, Poterba \& Summers 1991; Jegadeesh \& Titman 1993; Mun, Vasconcellos \& Kish 2000) shows that various irregularities in the market (e.g. excess volatility, overreaction and underreaction to news announcements, equity premium puzzle) exist, which result in the mispricing of stocks; furthermore, they also show that these mispricings are not immediately corrected by rational traders as predicted by the EMH. This evidence indicates that the traditional finance models cannot fully explain the functioning of financial markets (Barberis \& Thaler 2002; Kourtidis, Sevic \& Chatzoglou 2011).

The inability of the traditional finance models to explain these irregularities in the market brought about the emergence of behavioural finance as a field of study. Contrary to the traditional finance framework, behavioural finance theory argues that the deviations of stock prices from its fundamental values may be attributed to the presence of irrational traders in the market (Barberis \& Thaler 2002). This implies to an extent that the decisions made by individual investors are not based on a company's fundamental values but are rather driven by their emotions. 
As a result, the finance literature often portrays individual investors as unsophisticated 'noise' traders who are subject to psychological biases (Kaniel et al. 2012). Therefore, this new phenomenon seems to suggest that some financial market anomalies might be better understood and explained by using financial models that relax the assumption of individuals being fully rational.

Various financial biases have been identified by critics of the EMH to support their arguments that investors are generally irrational. These biases include amongst others, overconfidence (Barber \& Odean 2001), mental accounting (Thaler 1985), regret and loss aversion (Kahneman \& Tversky 1979), herding (Lakonishok, Shleifer \& Vishny 1992), overreaction (De Bondt \& Thaler 1987) and familiarity (Huberman 2001). The latter bias has received extensive attention from researchers in the last two decades, which provides mounting evidence of the impact of familiarity on the investment decisions made by individuals.

Familiarity bias refers to the preference of individual investors to invest in the shares of companies that are familiar to them (Baker \& Nofsinger 2002; Grullon, Kanatas \& Weston 2004; Huberman 2001; Speidell 2009). If individuals are presented with two alternatives, they would generally prefer the alternative they are more familiar with rather than the unfamiliar. According to Fox and Tversky (1995), this preference is also demonstrated when selecting stocks for investment purposes. The inclination towards the familiar and the dislike or apprehension of the unfamiliar culminate in the basic result that investors simply prefer to invest in securities that are familiar to them (Huberman 2001). It appears that the behaviour of investors in the financial market is closely related to the behaviour of consumers in the product market. According to Chira, Adams and Thorton (2008), the perceptions individuals have about specific brands tend to be influenced by how familiar they are with the products associated with those brands. Aspara and Tikkanen (2008:85) promote the idea that individuals' attitudes towards a company, their tendency to invest in a company's shares and their tendency to buy the products of a company are likely to interact. This implies that individuals tend to invest in the shares of companies based on the good experiences they had with those companies' products and, conversely, individuals tend to buy products from companies in which they hold shares (Aspara \& Tikkanen 2008). Therefore, individual investors may prefer to invest in the shares of certain companies partly because of the positive attitudes they have towards the companies' products and brands (Aspara \& Tikkanen 2008).

This perspective on individual investment decisions is important. If stock holdings by individual investors are influenced by psychological features, such as familiarity bias, it could influence the prices of securities and have important implications for stock characteristics such as risk and return and, consequently, also firm value. Furthermore, familiarity bias would suggest that investors hold suboptimal investment portfolios. Therefore, reducing familiarity bias could result in greater diversification, which in turn could lead to higher returns and lower risk for investors. Thus, familiarity bias becomes an important factor to consider when focusing on individual investment decisions and the potential impact it could have on stock markets.

Extensive research (Baker \& Nofsinger 2002; Grullon et al. 2004; Huberman 2001) on the influence of familiarity bias on investment decision making has been conducted in various countries and provide ample evidence that this particular bias is present when individuals make investment decisions. Research on individual investors, per se, and specifically on the biases portrayed by these investors is limited within the South African context. Therefore, this article aims to contribute to the South African finance literature by investigating the presence of familiarity bias amongst individual investors. Based on the evidence from prior international studies (Baker \& Nofsinger 2002; Foad 2010; Grullon et al. 2004; Huberman 2001), it is expected that the phenomenon of familiarity will also be evident in the investment decisions of South African investors. If this is the case, it is important to investigate this topic further to determine the potential impact it can have on the investment decisions made by individuals as well as the South African stock market.

The section that follows reviews the psychological literature and how familiarity affects judgement and investment decision making. This section focuses specifically on literature from the field of behavioural finance as well as economic psychology. The methodology applied in an attempt to answer the research question as well as the empirical findings and deductions will then follow. The final section concludes by considering the implications of familiarity bias on asset valuation and relates the resulting distortions to traditional finance theory, before suggesting areas for future research relating to familiarity bias in investment decision making.

\section{Literature review}

An in-depth literature review was conducted and the following sections provide a discussion on the concepts of traditional finance and behavioural finance theories, the impact of familiarity bias on investment decisions and lastly the link between brand knowledge and investment decisions made by individuals.

\section{From traditional finance to behavioural finance}

Traditional finance theory suggests that the pricing of securities in financial markets should be done according to the quality of their underlying fundamentals (MacGregor et al. 2000:104). Furthermore, it seeks to give an understanding of financial markets using models (such as the capital asset pricing model and the arbitrage pricing theory) in which all investors are assumed to be fully rational (Barberis \& Thaler 2003:1053). Therefore, in the traditional finance framework where all investors are assumed to be rational, the price of a security should be equal to its fundamental value. 
This theory is based on the EMH that posits that all information has already been reflected in a security's price and that the current price that the security is trading for on any particular day is its fair value (CIMA 2012:93). If security prices deviate from their fundamental values, an attractive arbitrage opportunity is created. However, rational arbitrageurs in the market will immediately take up this arbitrage opportunity which will bring prices to their fundamental values, hence keeping markets efficient.

Another important feature of traditional finance theories is the trade-off between risk and return (Ricciardi \& Simon 2000). Theories of traditional finance predict a strong positive relationship between the risk and expected return of a security. The prediction of a positive risk-return relationship is based on the rationality of investors who judge risk and return characteristics exclusively based on the fundamental information of the particular security (Kempf, Merkle \& Niessen-Ruenzi 2014:995). This argument suggests that rational investors should hold well-diversified portfolios in which a collection of shares produces the maximum expected return given the amount of risk assumed.

Therefore, the central assumption of the traditional finance models is that individual investors are rational when making investment decisions and consequently hold well-diversified portfolios. However, several research papers have reported evidence that is contrary to these arguments of the traditional framework. Empirical evidence suggests that stock markets are not perfectly efficient, prices are not always equal to its fundamental values, individual investors do not always consider the risk and return characteristics of securities and overall they tend to hold poorly diversified portfolios. This contradicting evidence indicates that the basic understanding of the functioning of financial markets and the trading behaviour of individuals are not easily understood by the traditional finance framework (Barberis \& Thaler 2002; Kourtidis et al. 2011). According to Barber and Odean (2011:36), the contradicting evidence to the rationality assumption on which the traditional finance models were built show that the investors who inhabit the real world and those who populate academic models are distant cousins (Barber \& Odean 2011:36). Nagy and Obenberger (1994) argue that the traditional finance models cannot fully explain the functioning of financial markets because these models focus on the development of macro models that explain aggregate market behaviour and do not typically address the decision process of individual investors. This resulted in a shift in the focus of finance research from the aggregate market behaviour to the behaviour of an average, sometimes irrational, individual investor. The significance of individual investors' participation in financial markets has led to the emergence of the field of behavioural finance, which is a subdiscipline of behavioural economics.

Behavioural finance examines the choices made by various financial market participants, from private individuals to institutional investors; furthermore, it examines how these choices affect financial markets (De Bondt et al. 2010).
Contrary to the traditional finance framework, behavioural finance suggests that deviations of security prices from their fundamental values may be attributed to the presence of irrational traders in the market (Barberis \& Thaler 2002). According to Barber and Odean (2001:288) 'behavioural finance relaxes the traditional assumptions of financial economics by incorporating observable, systematic, and very human departures from rationality into standard models of financial markets'. This implies to an extent that the investment decisions made by individual investors are not solely based on the fundamental values of a firm, but might rather be driven by their own emotions. Therefore, individual investors are often portrayed in the finance literature as unsophisticated 'noise' traders, who are subject to psychological biases (Kaniel et al. 2012). Therefore, contrary to traditional finance, behavioural finance theory considers psychological aspects to be of great importance in understanding the decision-making process of investors.

According to De Bondt et al. (2010), behavioural finance is informed by three strands of psychology to explain the behaviour of individual investors. The first strand, namely cognitive psychology, focuses on how the minds of individuals undertake the necessary calculations that are required to maximise wealth. The second strand is social psychology, which recognises the need to find acceptance of individuals' acts (De Bondt et al. 2010:31). Emotional responses to the intensity of trading is the third strand of psychology identified by De Bondt et al. (2010), which focuses on the decisionmaking process being more than a strictly calculative process (De Bondt et al. 2010:31).

The third strand, namely emotional responses, has received extensive attention by researchers in recent years in an attempt to explain and understand the reasoning patterns of investors, including the emotional processes involved and the degree to which they influence the decision-making process (Ricciardi \& Simon 2000:2). Various financial biases have been identified to support the argument that investors are irrational and base their decisions primarily on their emotions. These biases include amongst others, overconfidence (Barber \& Odean 2001), mental accounting (Thaler 1985), regret and loss aversion (Kahneman \& Tversky 1979), herding (Lakonishok et al. 1992), overreaction (De Bondt \& Thaler 1987) and familiarity (Huberman 2001).

In-depth research has been conducted to explain and justify all of above-mentioned biases. Familiarity bias in particular has received much attention by international researchers in the field of psychology and behavioural finance. This bias appears to be a dominant factor in explaining the irrationality of individual investors and, thus, forms the focal point of this article.

\section{Familiarity bias}

When individuals are presented with two alternatives, they will usually prefer the alternative they are more familiar with (Fox \& Tversky 1995). This notion is also 
valid when deciding on which stocks to include in an investment portfolio. According to Huberman (2001), the preference for the familiar and the distaste for the unfamiliar causes individuals to invest in the stocks of companies they are familiar with. Therefore, familiarity bias is the preference for investing in the shares of companies that are familiar to the individual investor (Baker \& Nofsinger 2002; Grullon, et al. 2004; Huberman 2001; Speidell 2009). This finding contradicts the traditional finance framework because it suggests that individuals, in part, base their investment decisions on their familiarity and association with a stock rather than on the fundamentals of that particular stock.

There are a couple of rationales for the existence of familiarity bias in investment decisions. Firstly, there is the argument of professional or geographical proximity, which suggests that investors tend to invest in the stock of companies they work for and they are also more likely to invest in the stock of companies that are located near them (Massa \& Simonov 2002). This behaviour by investors may be attributed to the fact that they feel more comfortable with companies that they know well and/or hear about frequently. A further explanation for familiarity bias is suggested by a lack of diversification (Foad 2010:277). According to Boyle et al. (2012), investors tend to hold a substantial amount of their overall investment in just a few assets, often those with which they are familiar, instead of holding a well-diversified portfolio. When investors limit their investment portfolio to only stocks that are familiar to them, they may forfeit higher returns and lower risks available in other unfamiliar securities. This strong preference for familiar securities consequently results in a lack of portfolio diversification. Lastly, asymmetric information is considered as another rationale for familiarity bias and suggests that investors may choose to invest in familiar securities simply because they have more information about it (Foad 2010:286). Investors are exposed to asymmetric information when dealing with assets that are unfamiliar to them. These information asymmetries are relevant, especially when considering investments in foreign assets (Foad 2010). Studies find that investors prefer to invest in local assets with which they are more familiar, in spite of the benefits and gains from international diversification (Foad 2010:278). Investors' preference for local assets as opposed to foreign assets is referred to as local and home bias. Numerous studies have suggested that local bias might be a rational response to better information and knowledge about familiar assets (Foad 2010:279).

Together, these rationales provide strong evidence that individuals invest in the familiar while often ignoring the principles of portfolio theory (Huberman 2001:659). The general conclusion of researchers is that people prefer to bet in an environment where they consider themselves knowledgeable or competent rather than in an environment where they feel ignorant or uninformed (Huberman 2001:660). Therefore, it is unlikely that an investor would choose to invest in a company without having any prior knowledge of that particular company. Familiarity bias is also evident in the marketing sector. According to Chira et al. (2008:13), individuals' perceptions of brands are influenced by how familiar they are with the products associated with those particular brands. When making a purchasing decision, consumer confidence is usually higher if familiarity with a particular brand is higher, which might often result in a decision that is faster and produces results consumers feel more comfortable with (Chira et al. 2008:13). This purchasing behaviour of consumers in the market section seems to spill over to the behaviour portrayed by individual investors in the stock market. Frieder and Subrahmanyam (2005) report results that support this notion that individuals prefer to invest in stocks of companies of which they have more information and knowledge about. This behaviour was actually encouraged by one of the best mutual fund managers of all time, Peter Lynch, who wrote 'buy what you know' (Lynch \& Rothchild 2000). According to Lynch, one is more likely to be successful if one invests in companies that are familiar (Ferri 2014)

\section{The link between brand knowledge and investment decisions}

It appears that perceptions of companies' products and brands do not only possibly influence consumer behaviour but also the behaviour of individual investors when making investment decisions. Research by Aspara and Tikkanen (2010) suggests that individuals seem to be willing to invest in certain companies' stock beyond its expected financial risk and return characteristics. Aspara and Tikkanen (2010:3) identified two variables that explain the willingness to invest in stocks beyond its expected financial returns. The first variable is an individual's affective evaluation of a company's product brand. The second variable relates to the perceived personal relevance attached to domains (heterogeneous activities, areas of interests) presented by the company's product categories (Aspara \& Tikkanen 2010:213). These findings lend support to an earlier study conducted by Aspara and Tikkanen (2008:85), which introduced the idea that individuals' attitudes towards a company, their tendency to invest in a company's shares and their tendency to buy the products of a company are likely to interact. This interaction is further complicated in the case of a relatively unfamiliar holding company with familiar subsidiary companies. Investors may have a strong positive affect with the subsidiary company, but may be unaware that this subsidiary forms part of a particular holding company. Therefore, individuals tend to invest in the shares of companies based on the good experiences they had with those companies' products and, conversely, individuals tend to buy products from companies in which they hold shares. Therefore, individual investors may prefer to invest in the shares of certain companies partly because of the positive attitudes they have towards the companies' products and brands (Aspara \& Tikkanen 2008). 
The consumption and investment markets have predominantly been considered to be isolated from each other. However, based on the extensive research in the field of behavioural finance, and in particular familiarity bias in investment decision making, it seems pivotal that these two fields of study should not be viewed in isolation, but rather as complements to each other.

\section{Research objectives and hypotheses}

Extensive research on the topic of familiarity bias in individual investment decision making has been conducted in various countries, which provide ample evidence that this particular bias is portrayed in the investment decisions made by individuals (Aspara \& Tikkanen 2008; Baker \& Nofsinger 2002; Foad 2010). Despite the majority of international research in the field of behavioural finance and in particular on familiarity bias, there seems to be a paucity of research in South Africa. It would seem that this article appears to be the first in South Africa to investigate the effect of familiarity bias on investment decisions in South Africa. Therefore, this article contributes to the South African literature by investigating the existence of familiarity bias amongst individual investors in South Africa. Therefore, the main research objective of this article was to assess if there is a difference between individuals' likelihood to invest in familiar corporate brands compared to unfamiliar corporate brands. Given this objective, the following hypotheses were postulated:

$H_{1}$ : There is a difference between individuals' likelihood to invest in familiar corporate brands compared to unfamiliar corporate brands.

$\mathrm{H}_{2}$ : There is a difference between individuals' likelihood to invest in a subsidiary company compared to its listed holding company's corporate brand.

\section{Methodology Materials and procedure}

In current literature, the majority of studies measure familiarity by asking respondents to describe their knowledge and evaluations of a particular company. Alternatively, respondents are asked to indicate on a rating scale their familiarity or identification with a specific brand (Aspara 2013; Aspara \& Tikkanen 2011). In these questions, the name of the company is usually provided instead of an image or picture relating to the brand of the company. In the endeavour to assess the likelihood to invest in a familiar corporate brand compared to the likelihood to invest in an unfamiliar corporate brand, brand measurement theory was applied to measure brand familiarity. Researchers concur that in the measurement of brand familiarity, information on brand awareness should be collected (Aaker 1996; Hart \& Murphy 1998; Hoyer \& Brown 1990). Brand awareness refers to individuals' ability to identify a brand under different conditions (Aaker 1996; Kotler \& Keller 2006) and enable researchers to quantify levels and trends in brand knowledge (Farris et al. 2006). As individuals do not recall all brands equally often or with equal ease (Tybout \& Calkins 2005), Keller (2003) suggests that aided measures of brand awareness could be used. These measures include individuals being required to discriminate between a stimuli, which might be words, objects or images, as something they have previously seen (Farris et al. 2006; Keller 2003). For purposes of this article, respondents were requested to differentiate between various companies' brands (i.e. images or 'pictures'). Specifically, companies' listed corporate brands were used.

In selecting the relevant listed corporate brands used in this article, the researchers selected 10 brands that they considered to be unfamiliar and 20 brands that they considered to be familiar based on company size. The 10 unfamiliar brands represent small companies that were classified as Small Cap shares on the JSE (J202), while the 20 familiar brands correspond to larger companies that were constituents of either the FTSE/JSE Top 40 (J200) or the FTSE/JSE Mid Cap (J201) indices. In an attempt to classify these 30 corporate brands as familiar and unfamiliar, the brands were presented to 20 management experts (financial, investment and marketing) in a pilot study. Results of the pilot study allowed for seven brands to be included in the final questionnaire. Of these seven brands, four brands were rated as very familiar (SAB Miller, Foschini Group, Truworths, and Pick n Pay) and three were rated as very unfamiliar (Austro, Deep Yellow and Corwill Investment Holdings). The corporate brands used to assess brand familiarity are illustrated in Table 1.

When using corporate brands to measure brand familiarity, care should be taken to ensure that the correct colours and images are displayed to respondents. As a result, an online survey was conducted, ensuring that all brands were correctly displayed. Unfortunately, a major disadvantage of online surveys is low response rates; this was countered by offering respondents an incentive to participate.

\section{Data collection instrument}

Because brand familiarity relates to individuals' ability to retrieve the brand from memory when given a cue, corporate brand familiarly was assessed two-fold. Respondents were given seven corporate brands and asked to indicate on a 5-point semantic differential scale whether they will buy a specific company's shares ( 1 = will definitely not buy shares and $5=$ will definitely buy shares). Demographic questions such as age and gender, as well as attitudinal questions on past investment behaviour and attitude towards investment, were also included in the data collection instrument.

The reliability of the data was tested by means of the splithalf method, using a single questionnaire item to test the reliability. In this case, respondents' willingness to invest a portion of R10 000 in the share market was used. The data pertaining to this questionnaire item were split by separating the data according to the participants' response numbers. Those participants who submitted their questionnaires first, third, fifth, etc., were grouped and those who submitted the questionnaires second, fourth, sixth, etc., were grouped. 


\section{FOSCHINI GROUP}

The two halves were compared to each other by means of a correlation analysis; according to Coldwell \& Herbst (2004:17), the greater the degree of the correlation between the two halves, the greater the reliability of the scale is considered to be. The result of the split-half reliability test is presented in Table 2.

The results in Table 2 suggest that there is a moderately significant relationship between the two halves of the data $(r=0.34)$. Thus, one can conclude that the scale is reliable (Coldwell \& Herbst 2004).

\section{The sample}

A convenience sample of students studying a variety of different B.Com. subjects and courses at one university participated in the study. As little research has been conducted in South Africa on the likelihood to invest, this article serves as an exploratory research study in the field of behavioural finance in South Africa, and using a student sample seemed appropriate. Although the participants may not have been actively involved in share investments, their exposure to a number of subjects that cover investment theory should have raised their awareness of the factors that should be considered during the investment decision-making process. In other words, by sampling these students, one would expect that they would be sensitive to aspects that could influence investment decisions. A total of 500 students participated in the study. Preliminary investigation indicated that, on average, the questionnaire took about 6 minutes to complete ( $s=52$ seconds). Therefore, to ensure that results gained were valid, all questionnaires that were completed in less than
TABLE 2: Split-half reliability analysis.

\begin{tabular}{lccc}
\hline Variable & $\boldsymbol{N}$ & Correlation & Significance \\
\hline Uneven numbered & 220 & 0.342 & $0.035^{*}$ \\
Even numbered & 219 & & \\
\hline
\end{tabular}

*, Correlation significant at the 0.05 level.

3 minutes were discarded. As a result, 439 completed, valid observations could be used for data analysis purposes.

\section{Results}

\section{The realised sample}

The sample consisted of $53 \%$ male and $47 \%$ female respondents. The average age of the respondents was 20 years $(s=1.6 ; 17 \leq x \leq 30)$. The majority of the respondents were B.Com. Management Studies students (56\%) and 14\% were B.Com. Accounting students. The minority of the respondents (23\%) indicated that they have purchased shares in the past. Even though only $23 \%$ of the respondents indicated that they had bought shares in the past, preliminary data analysis indicated that there were no significant differences in the investment behaviour between respondents who had bought shares in the past and those who had not $(t(317)=1.893$; $p>0.05)$. Those who had bought shares in the past spent, on average, R32 233 on share purchases ( $s=$ R62 154; R200 $\leq$ $x \leq \mathrm{R} 500$ 000). Respondents were asked to indicate how much (out of a total R10 000) they would be willing to invest in the stock market in a month. On average, respondents indicated that they will spend R1672 on stock market investments $(s=\mathrm{R} 1572 ; 0 \leq x \leq \mathrm{R} 10000)$.

As previously mentioned, a secondary objective that was formulated was to determine if individuals differentiate 
between companies' listed corporate brands when deciding on which companies to invest in. This objective has led to the following hypothesis:

$H_{1}$ : There is a difference between individuals' likelihood to investment in familiar corporate brands versus unfamiliar corporate brands.

In order to test the postulated hypothesis, respondents were requested to differentiate between various companies' brands (i.e. images or 'pictures'). Specifically, companies' listed corporate brands were used. By conducting a one-way analysis of variance (ANOVA), the null hypothesis was rejected, indicating that there is a difference between respondents' likelihood to invest in companies with familiar corporate brands compared to companies with unfamiliar corporate brands $(F(6)=169.375 ; p<0.000)$. The descriptive statistics given in Table 3 show that respondents were significantly more inclined to buy shares in the companies with familiar brands (mean scores: SAB Miller $=3.99$, Truworths $=3.10$, Pick n Pay $=3.69$ and Foschini $=3.05$ ) than unfamiliar brands (mean scores: Austro $=2.27$, Deep Yellow $=2.26$ and Corwill $=2.61$ ). By rejecting the null hypothesis, one can conclude that there is a significant difference between respondents' likelihood to invest in companies with familiar corporate brands compared to companies with unfamiliar corporate brands.

The second secondary objective was formulated to determine if individuals differentiate between a subsidiary company and its listed holding company's corporate brand when deciding on which company to invest in. This objective has led to the following hypothesis:

$\mathrm{H}_{2}$ : There is a difference between individuals' likelihood to invest in a subsidiary company compared to its listed holding company's corporate brand.

To substantiate the above finding of familiarity bias amongst the sample of respondents, a further one-way ANOVA was conducted. Six corporate brands were given and respondents were asked to indicate on a 5-point semantic differential scale whether they will buy a company's shares; only in this instance, three of the brands were those of holding companies and the other three brands were their subsidiaries. However, five holding and five subsidiaries were initially selected based on the pilot study in which a set of three holding companies and their subsidiaries was identified for the purposes of the research. These companies and their subsidiaries are illustrated in Table 4.

By conducting a one-way ANOVA on the set of holding companies and their subsidiaries, further empirical evidence is provided, which indicates that there is a difference between brand familiarity and individuals' investment decision making with regards to holding and subsidiary companies $(F(5)=86.926 ; p<0.000)$. The descriptive results given in Table 5 show that respondents were significantly more inclined to buy shares in the companies with familiar

TABLE 3: Descriptive statistics: Familiar versus unfamiliar corporate brands.

\begin{tabular}{|c|c|c|c|c|c|}
\hline Variables & $N$ & Minimum & Maximum & Mean & Standard deviation \\
\hline \multicolumn{6}{|l|}{ Unfamiliar } \\
\hline Austro & 439 & 1 & 5 & 2.27 & 0.91 \\
\hline Deep Yellow & 439 & 1 & 5 & 2.26 & 0.96 \\
\hline Corwill & 439 & 1 & 5 & 2.61 & 1.15 \\
\hline \multicolumn{6}{|l|}{ Familiar } \\
\hline SAB Miller & 439 & 1 & 5 & 3.99 & 1.02 \\
\hline Truworths & 439 & 1 & 5 & 3.10 & 1.14 \\
\hline Pick n Pay & 439 & 1 & 5 & 3.69 & 1.12 \\
\hline Foschini & 439 & 1 & 5 & 3.05 & 1.18 \\
\hline
\end{tabular}

TABLE 4: Corporate listed brands of holding companies and their subsidiaries. 
TABLE 5: Descriptive statistics: Holding company versus subsidiary company.

\begin{tabular}{|c|c|c|c|c|c|}
\hline Variables & $N$ & Minimum & Maximum & Mean & Standard deviation \\
\hline \multicolumn{6}{|l|}{ Holding companies } \\
\hline Pioneer $^{\mathrm{a}}$ & 439 & 1 & 5 & 2.54 & 1.04 \\
\hline JD group ${ }^{b}$ & 439 & 1 & 5 & 3.44 & 1.20 \\
\hline Astral $^{c}$ & 439 & 1 & 5 & 2.64 & 1.11 \\
\hline \multicolumn{6}{|l|}{ Subsidiary companies } \\
\hline Sasko & 439 & 1 & 5 & 2.09 & 0.91 \\
\hline Incredible connection ${ }^{\mathrm{b}}$ & 439 & 1 & 5 & 3.10 & 1.23 \\
\hline Country fair ${ }^{c}$ & 439 & 1 & 5 & 3.22 & 1.29 \\
\hline
\end{tabular}

Note: ${ }^{\mathrm{a}, \mathrm{b}, \mathrm{c}}$, denote holding and subsidiary company combinations.

corporate brands (mean scores: JD Group $=3.44$, Incredible Connection $=3.10$ and Country Fair $=3.22$ ) than unfamiliar corporate brands (mean scores: Sasko $=2.09$, Pioneer $=2.54$ and Astral =2.64). From the results of the one-way ANOVA, one can conclude that there is a significant difference between respondents' likelihood to invest in companies with familiar brands compared to companies with unfamiliar brands, even though the one company is the holding company and the other is its subsidiary.

\section{Conclusion and recommendations}

The results showed that respondents' likelihood to invest in companies with familiar corporate brands is higher than their likelihood to invest in companies with unfamiliar corporate brands. The results also showed that, not only are respondents' likelihood to invest in companies with familiar brands higher than their likelihood to invest in companies with unfamiliar brands but also they would rather invest in a company they know than a company they are not familiar with, even if the familiar company forms part of the unfamiliar company (namely, a subsidiary and its holding company). The notion that investment decision making could be influenced by corporate brand familiarity is thus supported. The findings from this study correspond with the findings from various other authors such as Frieder and Subrahmanyam (2005), Aspara and Tikkanen (2011) and Aspara (2013). These studies conclude that investors are more likely to invest in the stocks of companies they are familiar with. Aspara and Tikkanen (2011:1446) found that 'an individual's identification with a company has a positive effect on their determination to invest in the company's shares rather than in other companies' shares that have approximately similar expected financial return/risks'.

In marketing literature, it is often proposed that consumers' buying decisions are influence by brand familiarly, in that consumers would rather buy a product that is vaguely familiar than a product that is not familiar at all (Hoyer \& Brown 1990; Macdonald \& Sharp 2003). According to Inman and McAlister (1994:423), 'when choosing between an unfamiliar brand and a familiar brand, a consumer might consider the regret of finding that the unfamiliar brand performs more poorly than the familiar brand and thus be less likely to select the unfamiliar brand'. This notion is substantiated by the results of The Nielsen Global Survey of New Product sentiment that was conducted in 2012 (Nielsen.com 2013). It reports that $60 \%$ of global consumers with Internet access prefer to buy new products from a familiar brand rather than switch to a new brand. It would seem that the same argument could be made about investors' investment decisions. According to Frieder and Subrahmanyam (2005), the retail investor bases are greater for companies with more familiar brands. Aspara and Tikkanen (2011:1459) support this argument by reporting that individuals who identify with a company are more likely and willing to invest in the stock of that company compared to others.

Therefore, one could argue that if companies succeed in building strong brands that are familiar not only to consumers but also to investors, these companies could enjoy the added benefit of attracting potential investors based on their familiarity with the brand. According to Aspara and Tikkanen (2011:1459), this implication can help when it comes to the marketing of a company in the financial market, because individuals who identify with the company are potential targets when the company seeks to broaden its shareholder base.

However, management should be aware of the potentially distorting impact that familiarity bias could have on the efficient allocation of capital. In an efficient market (characterised by rational investors devoid of biased decision making), capital should flow towards companies that are able to generate an acceptable level of return. Familiarity bias could hinder this process by artificially lowering familiar companies' cost of capital, resulting in the inappropriate appraisal of investment opportunities' financial feasibility. The resulting suboptimal investment of capital will fail to generate sufficient returns, limiting the companies' ability to create value, and may ultimately compromise their longterm sustainability.

Investors should also be aware that the irrational investment behaviour that stems from familiarity bias could result in the mispricing of familiar companies relative to unfamiliar companies. Although greater demand for the shares of companies with familiar corporate brands by irrational investors would contribute to an increase in share prices, it would also result in the overvaluation of these shares. The price increases stemming from familiarity bias will only be sustainable if the familiar companies are able to deliver adequate financial performance to support the higher share prices. If a familiar company fails to deliver acceptable levels of financial performance, its share price would 
eventually readjust to a lower level. If investors are able to identify examples of severe mispricing caused by familiarity bias, they could benefit from the resulting arbitrage opportunities.

According to Buffet (2012), one needs to maintain emotional detachment if one wants to be a successful investor. This world-renowned investor warns investors to succumb to the investment mistake, which he refers to as the "The Peter Lynch bias'. According to Buffet, 'investing in what you know' can cause you to lose perspective and see only what you want to see in the stock (Sizemore 2012). If you like a company, it does not necessarily mean that it is a good investment and will deliver good returns on your investment. This behaviour can result in investors holding suboptimal portfolios, which may result in poor and often even negative investment returns.

The results of this exploratory study point towards investors exhibiting familiarity bias when choosing between different companies (brands) to invest in. Although a familiar corporate brand could be used to unlock access to investor capital, it would also open the door to unforgiving public scrutiny by financial market participants. Only those companies with the ability to deliver healthy financial performance by satisfying the needs of their customers would contribute towards sustainable value creation.

It is evident that the behaviour exhibited by individual investors can have implications for the marketing industry, financial markets, company performance as well as the investment performance of individual investors. Extensive further research is needed on the behaviour of individual investors in order to obtain a better understanding of their investment decision-making process and to what extent it could impact the various role players in the market.

\section{Limitations and suggestions for future research}

Preliminary data analysis on the realised sample indicated that there was no difference in the investment behaviour of respondents who had invested in the past and those who had not. It would seem that relatively inexperienced and firsttime investors may be at risk to be influenced by aspects such as brand familiarity to an even greater degree than more experienced investors when making investment decisions. In future research, this study can be replicated by distributing the questionnaire to investors who have a few years of investing experience. An experiment amongst experienced investors could also be conducted to assess the influence brand familiarity has on their investment decision making.

In future, this study can also be extended by investigating the characteristics of familiar companies and to link familiarity with financial performance to identify potential arbitrage opportunities. Researchers may also attempt to identify the predominant factors that induce investors to feel familiar with a company. Another aspect that could impact on a company's familiarity amongst investors is rebranding or renaming the company. Familiarity bias stems from investors' preferences to invest in companies they know. Rebranding or renaming a company could influence investors to feel less comfortable with investing in the company because of their unfamiliarity with the new brand/name.

\section{Acknowledgements Competing interests}

The authors declare that they have no financial or personal relationships which may have inappropriately influenced them in writing this article.

\section{Authors' contributions}

All three authors contributed equally to the research and writing of this article.

\section{References}

Aaker, D.A., 1996, Building strong brands, The Free Press, London.

Aspara, J., 2013, 'The role of product and brand perceptions in stock investing: Effects on investment considerations, optimism and confidence', Journal of Behavioral Finance 14(3), 195-212. http://dx.doi.org/10.1080/15427560.2013.819803

Aspara, J. \& Tikkanen, H., 2008, 'Interactions of individuals' company-related attitudes and their buying of the companies' stocks and products', Journal of Behavioral Finance 9(2), 85-94. http://dx.doi.org/10.1080/15427560802107462

Aspara, J. \& Tikkanen, H., 2010, 'Consumers' stock preferences beyond expected financial returns: The influence of product and brand evaluations', International Journal of Bank Marketing 28(3), 193-221. http://dx.doi.org/10.1108/ 02652321011036468

Aspara, J. \& Tikkanen, H., 2011, 'Corporate marketing in the stock market: The impact of company identification on individuals' investment behaviour', European Journal of Marketing 45(9), 1446-1469.

Baker, H.K. \& Nofsinger, J.R., 2002, 'Psychological biases of investors', Financial Services Review 11(2), 97-116.

Barber, B.M. \& Odean, T., 2001, 'Boys will be boys: Gender, overconfidence and common stock investment', The Quarterly Journal of Economics 116(1), 261-292. http://dx.doi.org/10.1162/003355301556400

Barber, B.M. \& Odean, T., 2011. The behavior of individual investors, viewed 17 August 2014, from http://ssrn.com/abstract=1872211

Barberis, N. \& Thaler, R.H., 2002, A survey of behavioral finance, viewed 15 August 2014, from http://papers.ssnr.com/sol3/papers.cfm?abstract_id=327880

Barberis, N. \& Thaler, R.H., 2003, 'A survey of behavioral finance', in G.M. Constantinides, M. Harris \& R. Stulz (eds.), Handbook of the Economics of Finance, pp. 1051-1121, Elsevier, Amsterdam.

Boyle, P., Garlappi, L., Uppal, R. \& Wang, T., 2012, 'Keynes meets Markowitz: The trade-off between familiarity and diversification', Management Science 58(2), 253-272. http://dx.doi.org/10.1287/mnsc.1110.1349

Buffet, W., 2012, Investing lessons: Avoiding the Peter Lynch Bias, viewed 8 July 2014, from http://www.forbes.com/sites/moneybuilder/2012/11/20/investing-lessonsavoiding-the-peter-lynch-bias/\#45c1dd0570b9

Chira, I., Adams, M. \& Thornton, B., 2008, 'Behavioral bias within the decision making process', Journal of Business \& Economics Research 6(8), 11-20.

CIMA Financial Strategy, 2012, BPP Learning Media Ltd, London.

Coldwell, D. \& Herbst, F., 2004, Business research, Juta and Co Ltd, Cape Town.

Cutler, D.M., Poterba, J.M. \& Summers, L.H., 1991, 'Speculative dynamics', The Review of Economic Studies 58(3), 529-546. http://dx.doi.org/10.2307/2298010

De Bondt, W.F.M., Forbes, W., Hamalainen, P. \& Muradoglu, G., 2010, 'What can behavioural finance teach us about finance?', Qualitative Research in Financial Markets 2(1), 29-36. http://dx.doi.org/10.1108/17554171011042371

De Bondt, W.F.M. \& Thaler, R., 1987, 'Further evidence on investor overreaction and stock market seasonality', The Journal of Finance 42(3), 557-581. http://dx.doi. org/10.1111/j.1540-6261.1987.tb04569.x

Farris, P.W., Bendle, N.T., Pfeifer, P.E. \& Reibstein, D.J., 2006, Marketing metrics: $50+$ metrics every executive should master, Wharton, Upper Saddle River, NJ.

Ferri, R., 2014, Peter Lynch was wrong, viewed 4 December 2014, from http://www. forbes.com/sites/rickferri/2014/09/05/peter-lynch-was-wrong/

Foad, H., 2010, 'Familiarity bias', in H.K. Baker \& J.S. Nofsinger (eds.), Behavioural finance: Investors, corporations, and markets, pp. 277-294, Wiley, Hoboken, NJ. 
Fox, C.R. \& Tversky, A., 1995, 'Ambiguity aversion and comparative ignorance', The Quarterly Journal of Economics 110(3), 585-603. http://dx.doi.org/10.2307/ 2946693

Frieder, L. \& Subrahmanyam, A., 2005, 'Brand perceptions and the market for common stock', Journal of Financial and Quantitative Analysis 40(1), 57-85. http://dx.doi. org/10.1017/S0022109000001745

'Global consumers more likely to buy new products from familiar brands', viewed 17 August 2014, from http://www.nielsen.com/za/en/press-room/2013/globalconsumers-more-likely-to-buy-new-products-from-familiar-b0.htm

Grullon, G., Kanatas, G. \& Weston, J., 2004, 'Advertising, breadth of ownership and liquidity', The Review of Financial Studies 17(2), 439-461. http://dx.doi.org/ $10.1093 /$ rfs/hhg039

Hart, S. \& Murphy, J., 1998, Brands: The new wealth creators, Macmillan Press, London.

Hoyer, W.D. \& Brown, S.P., 1990, 'Effects of brand awareness on choice for a common repeat-purchase product', Journal of Consumer Research 17(2), 141-148. http:// dx.doi.org/10.1086/208544

Huberman, G., 2001, 'Familiarity breeds investment', Oxford Journals 14(3), 659-680. http://dx.doi.org/10.1093/rfs/14.3.659

Inman, J. \& McAlister, L., 1994, 'Do coupon expiration dates affect consumer behavior?', Journal of Marketing Research 31(3), 423-428. http://dx.doi.org/ $10.2307 / 3152229$

Jegadeesh, N. \& Titman, S., 1993, 'Returns to buying winners and selling losers: Implications for stock market efficiency', Journal of Finance 48(1), 65-91. http:// dx.doi.org/10.1111/j.1540-6261.1993.tb04702.x

Kahneman, D. \& Tversky, A., 1979, 'Prospect theory: An analysis of decision under risk', Econometrica 47(2), 263-292. http://dx.doi.org/10.2307/1914185

Kaniel, R., Liu, S., Saar, G. \& Titman, S., 2012, 'Individual investor trading and return patterns around earnings announcements', The Journal of Finance 67(2), 639-680. http://dx.doi.org/10.1111/j.1540-6261.2012.01727.x

Keller, K.L., 2003, Strategic brand management: Building, measuring and managing brand equity, 2nd edn., Prentice-Hall, Upper Saddle River, NJ.

Kempf, A., Merkle, C. \& Niessen-Ruenzi, A., 2014, 'Low risk and high return - Affective attitudes and stock market expectations', European Financial Management 20(5) 995-1030. http://dx.doi.org/10.1111/eufm.12001
Kotler, P. \& Keller, K.L., 2006, Marketing management, 12th edn., Prentice-Hall, Upper Saddle River, NJ.

Kourtidis, D., Sevic, Z. \& Chatzoglou, P., 2011, 'Investors' trading activity: A behavioural perspective and empirical results', Journal of Socio-Economics 40(5), 548-557. http://dx.doi.org/10.1016/j.socec.2011.04.008

Lakonishok, J., Shleifer, A. \& Vishny, R., 1992, 'The impact of institutional trading on stock prices', Journal of Financial Economics 32(1), 23-43. http://dx.doi.org/ 10.1016/0304-405X(92)90023-Q

Lynch, P. \& Rothchild, J., 2000, One up on wall street: How to use what you already know to make money in the market, Simon \& Schuster Paperback, New York.

Macdonald, E.K. \& Sharp, B.M., 2003, 'Management perceptions of the importance of brand awareness as an advertising effectiveness', Marketing Bulletin 14(2), 1-15.

MacGregor, D.G., Slovic, P., Dreman, D.N. \& Berry, M., 2000, 'Imagery, affect and financial judgement', The Journal of Psychology and Financial Markets 1(2), 104-110. http://dx.doi.org/10.1207/S15327760JPFM0102_2

Massa, M. \& Simonov, A., 2002, Behavioural biases and investment, viewed 8 July 2014, from http://www.econ.yale.edu/ shiller/behfin/2002-04-11/massa-simonov. pdf

Mun, J.C., Vasconcellos, G.M. \& Kish, R., 2000, 'The Contrarian/Overreaction hypothesis: An analysis of the US and Canadian stock markets', Global Finance Journal 11(1-2), 53-72. http://dx.doi.org/10.1016/S1044-0283(00)00011-9

Nagy, R.A. \& Obenberger, R.W., 1994, 'Factors influencing individual investor behavior', Financial Analysts Journal 50(4), 63-68. http://dx.doi.org/10.2469/faj.v50.n4.63

Ricciardi, V. \& Simon, H.K., 2000, 'What is behavioral finance?', Business, Education and Technology Journal 2(2), 1-9.

Sizemore, C., 2012, Investing lessons: Avoiding the Peter Lynch Bias, viewed 4 December 2014, from http://www.forbes.com/sites/moneybuilder/2012/11/20/ investing-lessons-avoiding-the-peter-lynch-bias/

Speidell, L., 2009, 'Investing in the unknown and the unknowable - Behavioral finance in frontier markets', Journal of Behavioral Finance 10(1), 1-8. http://dx.doi. org/10.1080/15427560902719323

Thaler, R.H., 1985, 'Mental accounting and consumer choice', Marketing Science 4(3), 199-214. http://dx.doi.org/10.1287/mksc.4.3.199

Tybout, A.M. \& Calkins, T., 2005, Kellogg on branding, Wiley, Hoboken, NJ. 